\title{
SCREENING OF TOTAL PHENOL AND FLAVONOID CONTENT IN DIFFERENT CYTOTYPES OF TWO SPECIES OF ACHYRANTHES LINN. FROM WESTERN HIMALAYA, INDIA
}

\author{
MANJIT INDER SINGH SAGGOO' ${ }^{1}$, LOVLEEN ${ }^{2}$ \\ 1Department of Botany, Punjabi University, Patiala 147002, Punjab, India, ${ }^{2}$ Department of Botany, DAV College, Jalandhar 144008, \\ Punjab, India
}

Email: ms.lovleen7@gmail.com

Received: 07 May 2017 Revised and Accepted: 31 Aug 2017

\begin{abstract}
Objective: Genus Achyranthes Linn. belonging to family Amaranthaceae consists of six species. The present study was undertaken to screen the phenolic components in the different cytotypes of two species of Genus Achyranthes Linn. growing in western Himalaya, India.

Methods: Methanol extract of leaves was used to determine the total phenol and flavonoid contents in different cytotypes of $A$. aspera Linn. and $A$. bidentata Blume by spectrophotometric method. Total phenol content was expressed as mg gallic acid g-1 phenol and total flavonoid content as mg quercetin $\mathrm{g}^{-1}$ flavonoid using the standard curves. Further, gallic acid content in methanol extracts of leaves was determined by RP-HPLC method using C-18 column, employing $0.01 \%(\mathrm{v} / \mathrm{v})$ orthophosphoric acid: acetonitrile $(98: 2 \mathrm{v} / \mathrm{v})$ as mobile phase at a flow rate of $1 \mathrm{ml} / \mathrm{min}$ with ultraviolet (UV) detection at $272 \mathrm{~nm}$.

Results: Hexaploid plants of $A$. aspera Linn. possess the higher amount of phenol $(9.16 \pm 0.84 \mathrm{mg} / \mathrm{g})$ and flavonoid (78.36 $\pm 1.63 \mathrm{mg} / \mathrm{g})$ constituents in the methanol extract of leaves as compared to its dodecaploid counterparts ( $7.86 \pm 0.08 \mathrm{mg} / \mathrm{g}$ and $70.20 \pm 1.81 \mathrm{mg} / \mathrm{g}$ respectively). Similarly, phenol and flavonoid content is found to be more in the methanol extract of leaves of hexaploid plants of $A$. bidentata Blume (11.93 \pm 0.59 mg/g and $115.92 \pm 1.32 \mathrm{mg} / \mathrm{g}$ respectively) as compared to its dodecaploid counterparts ( $9.46 \pm 0.75 \mathrm{mg} / \mathrm{g}$ and $107.76 \pm 0.94 \mathrm{mg} / \mathrm{g}$ respectively). Further, RPHPLC analysis of gallic acid revealed that higher amount of gallic acid is present in dodecaploid plants of $A$. aspera Linn. (1.04 $\pm 0.02 \mathrm{mg} / \mathrm{g})$ and $A$. bidentata Blume $(1.34 \pm 0.03 \mathrm{mg} / \mathrm{g})$ as compared to hexaploid counterparts $(1.01 \pm 0.01 \mathrm{mg} / \mathrm{g}$ and $1.22 \pm 0.05 \mathrm{mg} / \mathrm{g}$ respectively).
\end{abstract}

Conclusion: The present investigation revealed that $A$. aspera Linn. and A. bidentata Blume plants show immense intraspecific variability in their phenolic components. Hence there is need to evaluate germplasm to select superior genotype for medicinal and conservation purpose.

Keywords: Achyranthes Linn, Cytotypes, Total phenols, Total flavonoids, Western Himalaya

(C) 2017 The Authors. Published by Innovare Academic Sciences Pvt Ltd. This is an open access article under the CC BY license (http://creativecommons.org/licenses/by/4.0/) DOI: http://dx.doi.org/10.22159/ijpps.2017v9i10.19780

\section{INTRODUCTION}

Achyranthes is a genus of about six species in tropical and subtropical regions, mostly in Africa and Asia [1]. Out of three species of the genus available in India, A. aspera Linn. is distributed throughout India and commonly found on hillsides, waste places, roadsides and riverbanks up to the ranges of $2300 \mathrm{~m}$ while $A$. bidentata Blume grows in temperate and subtropical Himalaya from Kishtwar to Sikkim, Khasia Hills, Bihar, Konkan, Nilgiris and Travancore at an elevations of $1200 \mathrm{~m}-2400 \mathrm{~m}$.

Traditionally, A. aspera Linn. is used in asthma, cough, oedema, dropsy, piles, boils, eruptions of skin, pneumonia, snake bites and night blindness. It is pungent, antiphlegmatic, antiperiodic, diuretic, purgative and laxative [2]. Ash of the plant is applied externally to ulcers and warts. The crushed leaves rubbed on aching back cure strained back [3]. A fresh piece of root is used as tooth brush. A paste of the roots in water is used in ophthalmia and opacities of the cornea. A paste of fresh leaves is used for allaying pain from the bite of wasps [4]. Inhaling the fumes of $A$. aspera mixed with Smilax ovalifolia roots is suggested to improve appetite and to cure various types of gastric disorders [5]. The plant is useful in liver complaints, rheumatism, scabies and other skin diseases.
As an important medicinal herb, the plant of $A$. bidentata Blume is used against whooping cough, abdominal pain, backache, trauma, pain and difficulty in movement of knees, blisters in the mouth and cholera, scorpion sting and malarial fever. The plant is diuretic and astringent [6-8].

Further, a perusal of the literature revealed the occurrence of different cytotypes among these species. Therefore, the present investigation has been taken up to evaluate these species with immense medicinal importance for their bioactive contents depending upon their different ploidy levels. The present study is the first attempt to carry out the investigation of total phenol, total flavonoid and gallic acid content in different cytotypes of A. aspera Linn. and $A$. bidentata Blume.

\section{MATERIALS AND METHODS}

Collection of plant material

The healthy plants of $A$. aspera Linn. and $A$. bidentata Blume were collected from different localities in western Himalaya of India (table 1). Identification of the specimens was done at Botanical Survey of India, Dehra Dun, India. Voucher specimens have been deposited in the Herbarium, Department of Botany, Punjabi University, Patiala (PUN).

Table 1: Chromosome number, ploidy, locality with altitude and accession number (PUN) of different cytotypes of Achyranthes aspera Linn and Achyranthes bidentata Blume from western Himalaya, India

\begin{tabular}{lllll}
\hline Taxa & Chromosome number (2n) & Ploidy & Locality with altitude (m) & Accession number (PUN) \\
\hline A. aspera Linn. & 42 & Hexaploid & Tathal (Himachal Pradesh), 1100 m & 59410 \\
A. aspera Linn. & 84 & Dodecaploid & Dheera (Himachal Pradesh), 500 m & 59411 \\
A. bidentata Blume & 42 & Hexaploid & Dharamkot (Himachal Pradesh), 2100 m & 58572 \\
A. bidentata Blume & 84 & Dodecaploid & Rehlu (Himachal Pradesh), 950 m & 58575 \\
\hline
\end{tabular}




\section{Chemicals and reagents}

Acetic acid (Fisher Scientific), chloroform (Merck), ethanol (Changshu Yangyuan Chem), acetocarmine (BDH), Folin-Ciocalteu reagent (Loba Chemie), anhydrous $\mathrm{Na}_{2} \mathrm{CO}_{3}$ (S D Fine Chem), $\mathrm{NaNO}_{2}$ (Sarabhai M Chemicals), $\mathrm{AlCl}_{3}$ (S D Fine Chem) and $\mathrm{NaOH}$ (Loba Chemie) used were of analytic grade. Methanol (Merck), gallic acid (HiMedia), quercetin (Sigma-Aldrich), orthophosphoric acid (Loba Chemie) and acetonitrile (Merck) used were of HPLC grade.

\section{Meiotic analysis}

For meiotic analysis, the young floral buds of suitable size were fixed in Carnoy's fixative ( 6 alcohol: 3 chloroform: 1 acetic acid v/v/v) for $24 \mathrm{~h}$ and then preserved in $70 \%$ alcohol at $4{ }^{\circ} \mathrm{C}$ until use. For the cytological studies, anthers were squashed in $2 \%$ acetocarmine. A number of slides were carefully examined for chromosome counts. Photomicrographs of chromosome counts were made from freshly prepared slides using 80i Eclipse Microscope.

\section{Extract preparation}

The leaves of the selected plants were washed thoroughly and air dried in shade at room temperature. The dried leaves were ground into a coarse powder with a mechanical grinder and stored in air tight containers at room temperature for further use. $1 \mathrm{~g}$ powder of each cytotype was suspended in $50 \mathrm{ml}$ methanol for $48 \mathrm{~h}$ at room temperature with occasional stirring. After $48 \mathrm{~h}$, methanol extract was filtered with Whatman no. 1 filter paper. The filtrate was saved and allowed to dry at $37^{\circ} \mathrm{C}$ in an incubator for complete evaporation of methanol. The whole process was repeated three times and finally blackish-green coloured, concentrated leaf extract was obtained Dried extract was weighed and dissolved in methanol to make a final concentration of $100 \mathrm{mg} / \mathrm{ml}$ of extract and stored in the refrigerator until further use.

\section{Determination of total phenols}

Total phenol content determination was performed by using a modified Folin-Ciocalteu reagent method [9]. Folin-Ciocalteu reagent was diluted to 10 fold with double distilled water. $0.1 \mathrm{ml}$ of methanol extract of leaves was mixed with $7.9 \mathrm{ml}$ of double distilled water. Then, $0.5 \mathrm{ml}$ of diluted Folin Ciocalteu reagent was added and incubated for $3 \mathrm{~min}$ at room temperature. After that, $1.5 \mathrm{ml}$ of $20 \%$ of anhydrous $\mathrm{Na}_{2} \mathrm{CO}_{3}(\mathrm{w} / \mathrm{v})$ was added and mixed thoroughly. The mixture was incubated at room temperature for $2 \mathrm{~h}$. The absorbance of the sample was recorded at $765 \mathrm{~nm}$ using spectrophotometer (Shimadzu, UVmini-1240 UV-VIS Spectrophotometer) against a blank containing double distilled water instead of leaf extract. The experiment was conducted in triplicate. The total phenol content was determined as mg gallic acid g-1 phenol using the standard curve.

\section{Determination of total flavonoids}

Total flavonoid content was determined by the method proposed by Kim et al. [10] with minor modifications. $1 \mathrm{ml}$ of methanol extract of leaves was mixed with $4 \mathrm{ml}$ of double distilled water. Then, $0.3 \mathrm{ml}$ of $5 \% \mathrm{NaNO}_{2}(\mathrm{w} / \mathrm{v})$ was added and incubated for $5 \mathrm{~min}$ at room temperature. Later, $0.3 \mathrm{ml}$ of $10 \% \mathrm{AlCl}_{3}(\mathrm{w} / \mathrm{v}), 2 \mathrm{ml}$ of $1 \mathrm{M} \mathrm{NaOH}$ and $2.4 \mathrm{ml}$ of double distilled water was added. The mixture was incubated up to $30 \mathrm{~min}$ at room temperature and absorbance was measured at $510 \mathrm{~nm}$ using spectrophotometer (Shimadzu, UVmini1240 UV-VIS Spectrophotometer). The experiment was performed in triplicate. The total flavonoid content was determined as $\mathrm{mg}$ quercetin g-1 flavonoid using the standard curve.

\section{RP-HPLC conditions}

Reverse phase-high performance liquid chromatography (RP-HPLC) was used for the detection of gallic acid. RP-HPLC was performed by modifying the method proposed by Rakesh et al. [11]. HPLC (Shimadzu) C-18 column with dimensions $250 \mathrm{~mm} \times 4.6 \mathrm{~mm}$ and particle size $5 \mu \mathrm{m}$ was used. The column temperature was maintained at $30{ }^{\circ} \mathrm{C}$. Mobile phase used was $0.01 \%(\mathrm{v} / \mathrm{v})$ orthophosphoric acid: acetonitrile $(98: 2 \mathrm{v} / \mathrm{v})$ with a flow rate of $1 \mathrm{ml} / \mathrm{min}$. The injection volume was $20 \mu \mathrm{l}$ and detecting wavelength was $272 \mathrm{~nm}$. The mobile phase was filtered through a $0.45 \mu \mathrm{m}$ membrane filter.

\section{RESULTS AND DISCUSSION}

\section{Chromosome number}

The meiotic analysis was carried out on different populations of $A$. aspera and $A$. bidentata from western Himalaya, India. The existence of two different chromosome counts of $2 n=42,84$ (fig. 1) was observed in both the studied species of Achyranthes. The species are hexaploid $(2 n=42)$ and dodecaploid $(2 n=84)$ based on base number $x=7$ [12]. The present chromosome counts are in conformity with the earlier reports from India and elsewhere [13-38]. However, varied chromosome reports have also been reported earlier for $A$ aspera i.e. $2 \mathrm{n}=14,36,48$ and 96 [39-41] and $A$. bidentata i.e. $2 \mathrm{n}=34$, $35,36,38[36,42]$.
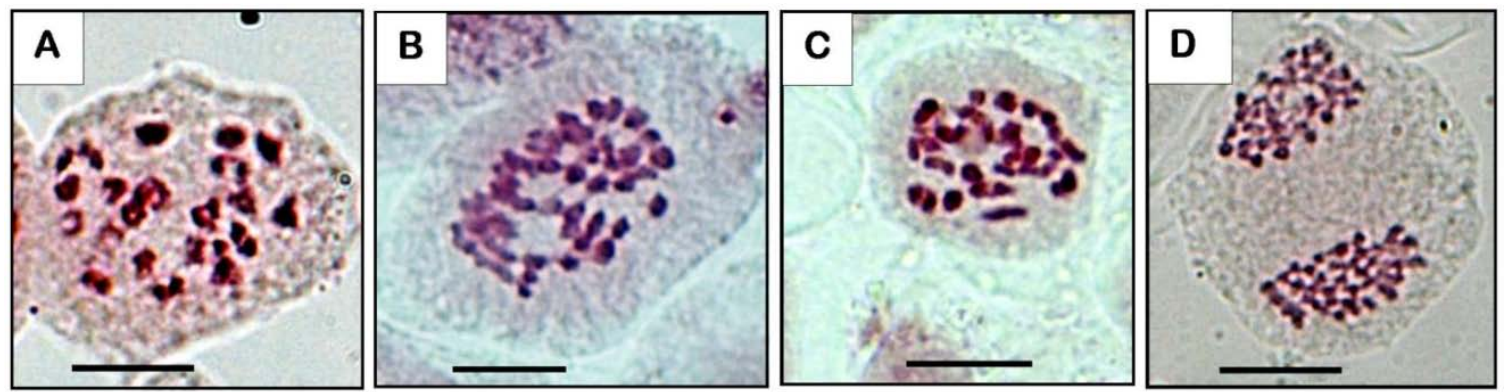

Fig. 1: A-B: Achyranthes aspera Linn.: A. A PMC at metaphase-I showing 21 bivalents, B. A PMC at metaphase-I showing 42 bivalents; C-D Achyranthes bidentata Blume: A PMC at diakinesis stage showing 21 bivalents, b. A PMC at metaphase-II showing 42:42 distribution of chromosomes. Scale bar $=10 \mu \mathrm{m}$

\section{Phenol and flavonoid estimation}

The amount of phenol and flavonoid contents in leaf extracts of $A$ aspera and $A$. bidentata were estimated by spectrophotometric method. Gallic acid was used as a standard compound and total phenolic content was expressed as mg gallic acid g-1 using the equation based on the calibration curve (fig. 2): $y=0.0007 x$ $\mathrm{R}^{2}=0.9946$, where $\mathrm{y}$ is an absorbance and $\mathrm{x}$ is $\mathrm{mg}$ gallic acid g-1.
The total flavonoid content was expressed as mg quercetin g-1 using the straight line equation based on the calibration curve of quercetin standard (fig. 3): $y=0.0006 x, R^{2}=0.9865$, where $y$ is an absorbance and $\mathrm{x}$ is the mg quercetin $\mathrm{g}-1$.

Total phenol and flavonoid contents of hexaploid cytotypes of both the species of Achyranthes are higher as compared to dodecaploid cytotypes of respective species (table 2). 


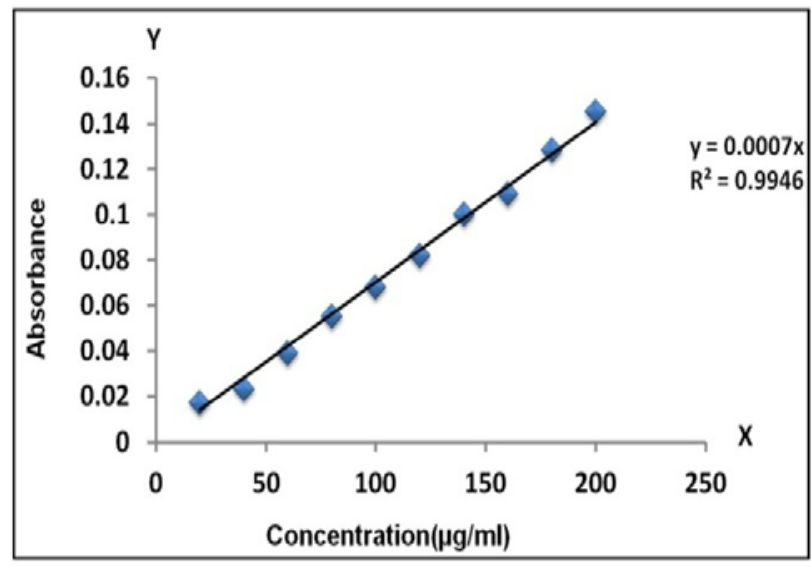

Fig. 2: Calibration curve for gallic acid

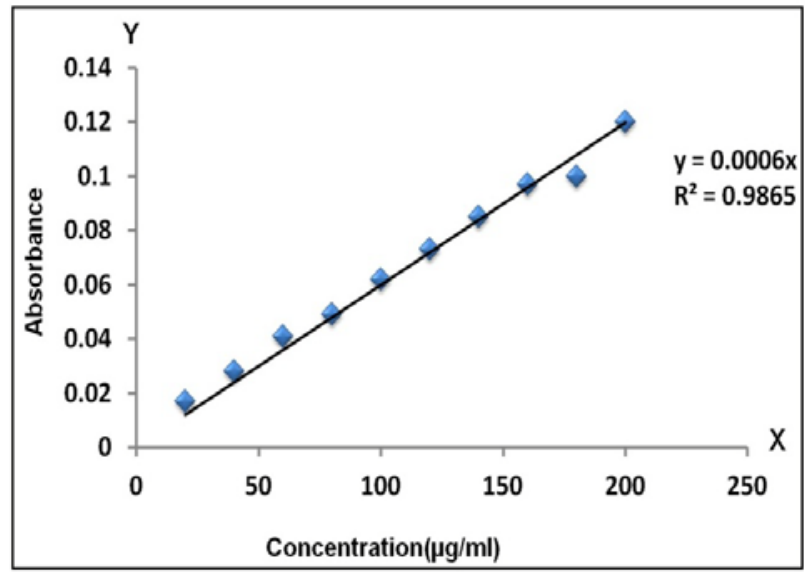

Fig. 3: Calibration curve for quercetin

Table 2: Total phenol and flavonoid content in leaf extract of hexaploid and dodecaploid cytotypes of $A$. aspera Linn. and A. bidentata Blume

\begin{tabular}{llll}
\hline Species & Cytotypes & Total phenol content $(\mathbf{m g} / \mathbf{g})$ & Total flavonoid content (mg/g) \\
\hline A. aspera Linn. & Hexaploid & $9.16 \pm 0.84$ & $78.36 \pm 1.63$ \\
& Dodecaploid & $7.86 \pm 0.08$ & $70.20 \pm 1.81$ \\
A. bidentata Blume & Hexaploid & $11.93 \pm 0.59$ & $115.92 \pm 1.32$ \\
& Dodecaploid & $9.46 \pm 0.75$ & $107.76 \pm 0.94$ \\
\hline
\end{tabular}

Data expressed as mean $\pm \mathrm{SD}[\mathrm{n}=3]$

Phenolic compounds, broadly distributed in the plant kingdom, are a major class of bioactive components. Phenols and flavonoids have drawn increasing attention due to their marked effects in the prevention of various diseases as these possess diverse biological activities, for instance, antioxidant [43], antitumor [44], antiulcer [45], anti-inflammatory $[43,46]$ and antidepressant activities [47, $48]$

Earlier, different leaf extracts of Achyranthes have been evaluated for different biological activities including antimicrobial activity [49, 50], anti-inflammatory activity [51], wound healing activity [52], anti-depressant effect [53], cancer chemo preventive activity [54], antinociceptive activity [55], analgesic activity [56], antifertility activities [57], anti-oxidant activity [58] and diuretic activity [59]

Screening of different phytochemical components from leaf extract has also been done earlier [50,60-62]. However, no report till date is available on the characterization of phenolic constituents in the leaves of A. aspera and A. bidentata having different ploidy level. The present attempt has been carried out to find out the variation in a number of phenolic constituents with variation in ploidy of the plant. In the present investigation, it has been observed that the plants of Achyranthes aspera and Achyranthes bidentata with the lower ploidy level i.e. hexaploids possess higher amount phenol and flavonoid constituents in the methanol extract of leaves as compared to its dodecaploid counterparts.

Further, RP-HPLC analysis was performed with the purpose of identifying and quantifying one of the phenolic compound i.e. gallic acid. Identification was performed by comparison of their retention's time and UV absorption spectrum with those of the standards. Five-point calibration curve of a standard sample of gallic acid is given in fig. 4. Fig. 5 shows the chromatograms obtained from the RP-HPLC separation of gallic acid with methanol extracts of different studied cytotypes of $A$. aspera and $A$. bidentata. Results revealed a considerable phytochemical (gallic acid) variation in the studied cytotypes of $A$. aspera and $A$. bidentata (table 3). Higher concentration of gallic acid is present in dodecaploid plants of $A$. aspera and A. bidentata as compared to hexaploid counterparts. 


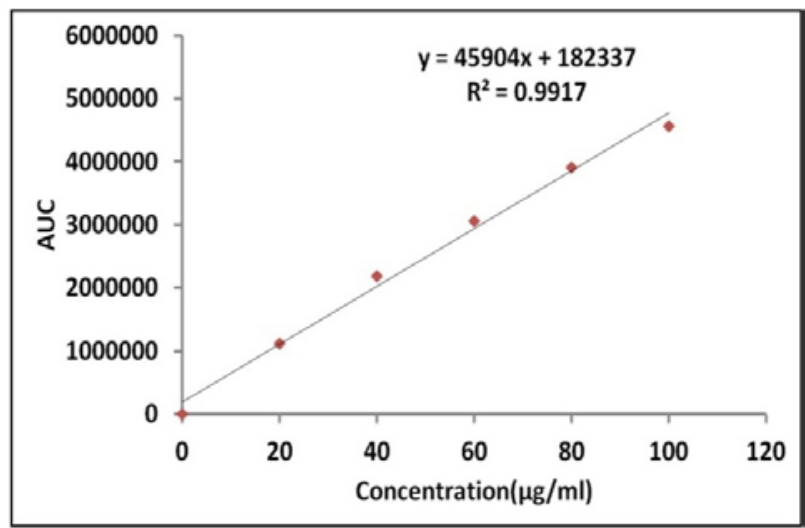

Fig. 4: Calibration curve for gallic acid
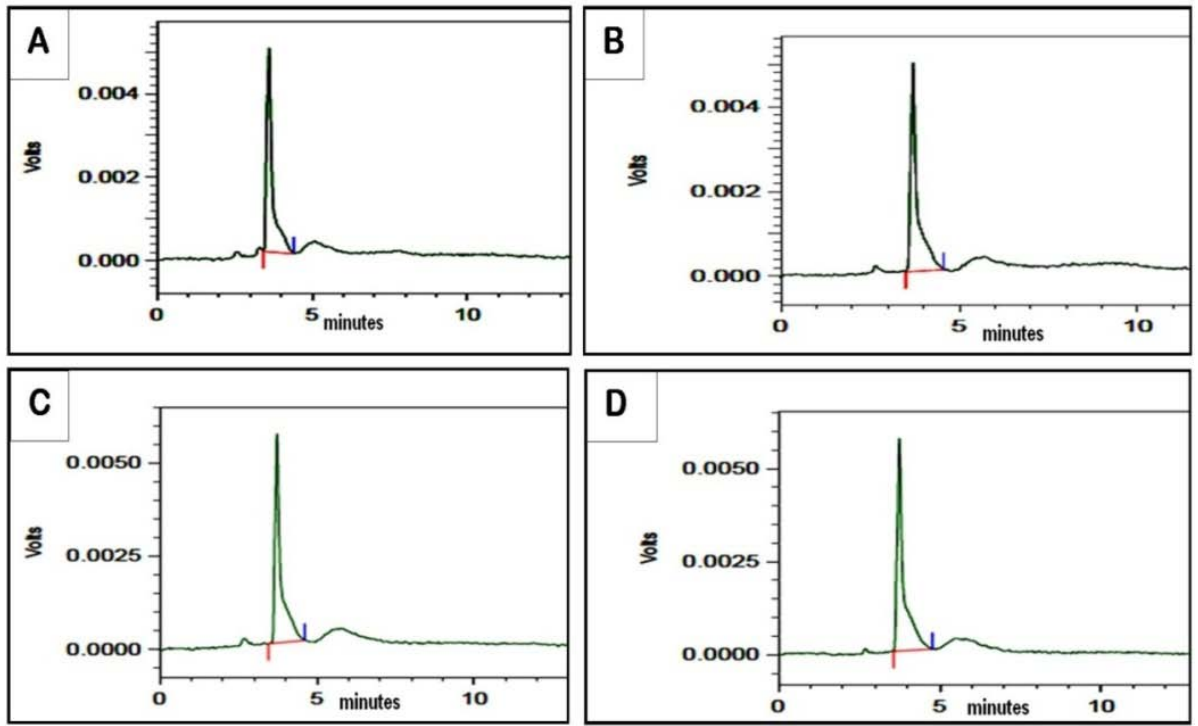

Fig. 5: RP-HPLC chromatograms of methanol extracts of leaves of A. Hexaploid cytotype of Achyranthes aspera Linn., B. Dodecaploid cytotype of Achyranthes aspera Linn., C. Hexaploid cytotype of Achyranthes bidentata Blume, D. Dodecaploid cytotype of Achyranthes bidentata Blume. Chromatograms show gallic acid

Table 3: Gallic acid content in the leaf extract of hexaploid and dodecaploid cytotypes of $A$. aspera Linn. and A. bidentata Blume

\begin{tabular}{|c|c|c|}
\hline Species & Cytotypes & Gallic acid (mg/g) \\
\hline \multirow[t]{2}{*}{ A. aspera Linn. } & Hexaploid & $1.01 \pm 0.01$ \\
\hline & Dodecaploid & $1.04 \pm 0.02$ \\
\hline \multirow[t]{2}{*}{ A. bidentata Blume } & Hexaploid & $1.22 \pm 0.05$ \\
\hline & Dodecaploid & $1.34 \pm 0.03$ \\
\hline
\end{tabular}

Data expressed as mean \pm SD $[n=3]$

Gallic acid is a poly phenolic compound and chemically known as 3, 4, 5-Trihydroxybenzoic acid. It is extensively used as a dietary herbal supplement as occurs in many plant materials in the form of esters, free acids, catechin derivatives and hydrolysable tannins. Gallic acid is evaluated for various biological activities including antioxidant, antimicrobial, anticancer, cardioprotective and neuroprotective [6367]. In addition, no report till date is reported for the determination of gallic acid in different cytotypes of $A$. aspera and $A$. bidentata.

\section{CONCLUSION}

Present investigation revealed that $A$. aspera Linn. and A. bidentata Blume plants show significant intraspecific variability in their total phenol, total flavonoid and gallic acid contents which may be accredited to the genotype of these species. The variation observed in presently studied bioactive constituents could be considered as an imperative factor for herbal formulation as the efficiency of the herbal remedy may be subjective to the type of genotype used for its preparation. Additionally, it recommends that there is a requirement for the selection of superior genotypes of these species of Achyranthes before recommending the same for therapeutic purpose and conservation.

\section{ACKNOWLEDGMENT}

The authors are grateful to the University Grants Commission, New Delhi for providing facilities under the DRS SAP III and ASIST programme. Financial assistance to one of us (Lovleen) by Department of Science and Technology, Government of India, New Delhi, under WOS-A is gratefully acknowledged. Thanks are also due to the Head, Department of Botany, Punjabi University, Patiala for necessary laboratory facilities. 


\section{AUTHORS CONTRIBUTION}

Saggoo MIS provided guidance and critical review. Lovleen researched and wrote this manuscript. Both authors read and approved the final version of this study.

\section{CONFLICT OF INTERESTS}

There is no conflict of interest among the authors

\section{REFERENCES}

1. Harwood RK, Palmer J. Amaranthaceae. In: Short PS, Cowie ID. editors. Flora of the Darwin region. Vol. 1. Australia: Northern Territory Herbarium, Department of Natural Resources, Environment, the Arts, and Sport; 2011. p. 1-23.

2. Nadkarni KM. Indian materia medica. Vol. I. Bombay Popular Prakashan; 2009. p. 21.

3. Singh VK, Ali ZA, Zaidi STH, Siddiqui MK. Ethnomedicinal uses of plants from gonda district forests of Uttar Pradesh, India. Fitoterapia 1996;67:129-39.

4. Gupta RK. Medicinal and aromatic plants. CBS publishers and distributors; 2010. p. 190.

5. Bhattarai NK. Folk herbal remedies of sindhupalchok district, central Nepal. Fitoterapia 1992;63:145-55.

6. Guha Bakashi DN, Sensarma P, Pal DC. A lexicon of medicinal plants in India. Vol. I. Calcutta (India): Naya Prokash (New Sarada Press); 1999.

7. Dhiman AK. Banaras ayurveda series 2-medicinal plants of Uttranchal state. Varanasi (India): Chowkhamba Press; 2004.

8. Pullaiah T. Encyclopedia of world medicinal plants. Vol. I. New Delhi (India): Regency Publications; 2006.

9. Singleton VL, Rossi JA. Colorimetry of total phenolics with phosphomolybdic-phosphotungstic acid reagents. Am J Enol Vitic 1965;16:144-58.

10. Kim DO, Chun OK, Kim YJ, Moon HY, Lee CY. Quantification of polyphenolics and their antioxidant capacity in fresh plums. J Agric Food Chem 2003;51:6509-15.

11. Rakesh SU, Patil PR, Salunkhe VR, Dhabale PN, Burade KB, Bhise SB. Quantitative estimation of gallic acid from hydroalcoholic extract of dried flowers of Nymphaea stellata willd by RP-HPLC. Asian J Chem 2010;22:5919-24.

12. Darlington CD, Wyile AP. Chromosome atlas of flowering plants. London: George Allen and Unwin Ltd; 1955.

13. Sugiura T. A list of chromosome numbers in angiospermous plants. Bot Mag 1931;42:504-6.

14. Sugiura T. Studies on the chromosome numbers in higher plants, with special reference to cytokinesis. Cytologia 1936; 7:544-95.

15. Ahuja MR. Chromosome number of some medicinal plants. In J Genet Plant Breed 1955;15:142-3.

16. Mall LP, Arzare KC. Autecological study of Achyranthes aspera Linn. Bull Bot Soc Uni Saugar 1956;8:69-76.

17. Sen S. Studies on the structure and behaviour of chromosomes of few species of the family Amaranthaceae. Proc 43rd Indian Sci Congr 1956;3:249.

18. Thombre MV. Chromosome numbers in some common flowering plants. Sci Cult 1959;25:208.

19. Roy RP, Thakur V. A comparative study of meiosis in two genera of the family Amaranthaceae. Proc 48th Indian Sci Congr 1961;3:303-4.

20. Roy RP, Thakur V. On a polyploidy Achyranthes bidentata $\mathrm{Bl}$ $(2 n=48)$ in nature. Proc 49th Indian Sci Congr 1962;3:335-6.

21. Pal M. Chromosome number in some Indian angiosperms. I. Proc Indian Acad Sci 1964;60:347-50.

22. Sharma AK, Banik M. Cytological investigations of different genera of amaranthaceae with a view to trace their interrelationships. Bull Bot Soc Bengal 1965;19:40-50.

23. Gill BS, Vasudeva S. Cytological studies in some members of amaranthaceae. Curr Sci 1970;39:445-6.

24. Sharma AK. Annual report 1967-68. Res Bull Univ Calcutta (Cytogenetics lab) 1970;2:1-50.

25. Kurosawa S. Cytological studies on some Eastern Himalayan plants and their related species. In: Hara H. editor. The flora of Eastern Himalaya. 2nd Report. Tokyo: University of Tokyo Press; 1971. p. 356-64.
26. Mittra R. Cytology of amaranthaceae. Proc 58th Indian Sci Congr 1971;3:470-1.

27. Miege J, Josserand N. Nombres chromosomiques d' especes africannes et malgaches. Candollea 1972;27:283-92.

28. Behera B, Patnaik SN. Cytotaxonomic studies in the family amaranthaceae. Cytologia 1974;39:121-37.

29. Van Loon JC. A cytological investigation of flowering plants from canary Island. Acta Bot Neerl 1974;23:113-24.

30. Koul AK, Wakhlu AK, Karihaloo JL. Chromosome number of some flowering plants of Jammu (Western Himalayas) II. CIS Chromosome Inf Serv 1976;20:32-3.

31. Sidhu MK. Distributional and cytological studies of weed flora of cultivable fields of patiala district (Punjab). Ph. D. Thesis, Patiala; 1979. p. 1-230.

32. Bir SS, Sidhu M. Cytological observations in weed flora of orchards of Patiala district, Punjab. Recent Res Adv Plant Sci 1979;7:261-71.

33. Bir SS, Sidhu M. Cytological observations on weed flora of orchards of Patiala district, Punjab. In: Bir SS. editor. Recent researches in plant sciences. Ludhiana (India): Kalyani Publishers; 1980. p. 261-71.

34. Sidhu M, Bir SS. Karyological studies on cultivable lands in Punjab, India. Trop Plant Sci Res 1983;1:1-13.

35. Dalgaard V. Chromosome numbers in flowering plants from Madeira. Willdenowia 1986;16:221-40.

36. Ge CJ, Li YK, Wan P, Hsu PS. Chromosome numbers of 31 medicinal plants from Shndong Province. In: Hong D. editor. Plant chromosome research 1987. Organising Committee Sino-Japanese Symposium on plant Chromosomes, Beijing; 1989. p. 267-72.

37. Ge CJ, Li YK, Wan P, Li YX, Jiang FH. Observations on the chromosome numbers of medicinal plants from shandong province (V). J Shandong Coll Trad Chin Med 1988;12:55-7.

38. Morton JK. Chromosome numbers and polyploidy in the flora of Cameroon mountain. Opera Bot 1993;121:159-72.

39. Malik NA, Ahmed AJ. Chromosome number in some medicinal plants. Pak J Sci Res 1963;15:58-60.

40. Sinha SSN, Prasad R, Keswani R. Cytological studies in some medicinal plants of Chhotanagpur. Proc 59th Indian Sci Congr 1972;3:349.

41. Kumar A. Polyploidy in Achyranthes aspera and Chrysanthemum leucenthemum. Acta Bot Indica 1982;10:141-2.

42. Mittra R. Cytology of amaranthaceae. Proc 58th Indian Sci Congr 1971;3:470-1.

43. Lu CL, Zhu W, Wang M, Xu XJ, Lu CJ. Antioxidant and antiinflammatory activities of phenolic-enriched extracts of Smilax glabra. J Evidence-Based Complementary Altern Med 2014:1-8. http://dx.doi.org/10.1155/2014/910438

44. Lim JH, Park JW, Kim MS, Park SK, Johnson RS, Chun YS, Bafilomycin induces the p21-mediated growth inhibition of cancer cells under hypoxic conditions by expressing HIF$1 \alpha$. Mol Pharmacol 2006;70:1856-65.

45. Barros MP, Lemos M, Maistro EL, Leite MF, Sousa JP, Bastos JK, et al. Evaluation of antiulcer activity of the main phenolic acids found in Brazilian green propolis. J Ethnopharmacol 2008;120:372-7.

46. Cuong TD, Hung TM, Lee JS, Weon KY, Woo MH, Min BS. Antiinflammatory activity of phenolic compounds from the whole plant of Scutellaria indica. Bioorg Med Chem Lett 2015;25:1129-34.

47. Yu ZF, Kong LD, Chen Y. Antidepressant activity of aqueous extracts of Curcuma longa in mice. J Ethnopharmacol 2002;83:161-5.

48. Lin SQ, Zhou ZL, Zhang HL, Yin WQ. Phenolic glycosides from the rhizomes of Cyperus rotundus and their antidepressant activity. J Korean Soc Appl Biol Chem 2015;58:685-91.

49. Saravanan P, Ramasamy V, Shivakumar T. Antimicrobial activity of leaf extracts of Achyranthes aspera Linn. Asian J Chem 2008;20:823-5.

50. Joshi B, Sah GP, Basnet BB, Bhatt MR, Sharma D, Subedi K, et al. Phytochemical extraction and antimicrobial properties of different medicinal plants: Ocimum sanctum (Tulsi), Eugenia caryophyllata (Clove), Achyranthes bidentata (Datiwan) and Azadirachta indica (Neem). J Microbiol Antimicrob 2011;3:1-7.

51. Amrutia JN, Patel J, Semuel MR, Shabaraya AR. Antiinflammatory activity of fractionated extracts of Achyranthes aspera Linn. leaves. J Appl Pharm Sci 2011;1:188-90 
52. Edwin S, Jarald EE, Deb L, Jain A, Kinger H, Dutt KR, et al Wound healing and antioxidant activity of Achyranthes aspera. Pharm Biol 2008;46:824-8.

53. Barua CC, Talukdar A, Begum SA, Buragohain B, Roy JD, Borah RS, et al. Antidepressant-like effects of the methanolic extract of Achyranthes aspera Linn. in animal models of depression. Pharmacologyonline 2009;2:587-94.

54. Chakraborty A, Brantner A, Mukuinaka T, Nobukuni Y, Kuchido M, Konoshima T. Cancer chemo preventive activity of Achyranthes aspera leaves on Epstein-Barr virus activation and two stage mouse skin carcinogenesis. Cancer Lett 2002;177:1-5.

55. Mehta FA, Patel BG, Pandya SS, Ahir KB, Patel SB. Antinociceptive and anti inflammatory activity of Achyranthes aspera L. extracts. Pharmacologyonline 2009;3:978-85.

56. Kumar H, Singh D, Kushwaha SKS, Gupta AK. Comparison of leaf and root extract of Achyranthes aspera for its analgesic activity. Pharm Lett 2009;1:193-8.

57. Shibeshi W, Makonnen E, Zerihun L, Debella A. Effect of Achyranthes aspera L. on fetal abortion, uterine and pituitary weights, serum lipids and hormones. Afr Health Sci 2006;6:108-12.

58. Tahiliani P, Kar A. Achyranthes aspera elevates thyroid hormone levels and decreases hepatic lipid peroxidation in male rats. J Ethnopharmacol 2000;71:527-32.

59. Niranjan S, Alok DK, Soumya MK, Priyanka G, Susri MS. Diuretic activity of Achyranthes aspera leaves extract. Int Res J Pharm 2012;3:216-8

60. Rafiqkhan M, Saranya. Pharmacognostic profile and phytochemical investigation on the leaves of Achyranthes aspera. Int J Pharm Pharm Sci 2013;5:368-70.

61. Hossain MJ, Khaleda L, Chowdhury AMMA, Arifuzzaman M, AlForkan M. Phytochemical screening and evaluation of cytotoxicity and thrombolytic properties of Achyranthes aspera leaf extract. J Pharm Biol Sci 2013;6:30-8.

62. Priya CL, Kumar G, Karthik L, Bhaskara Rao KV. Phytochemical composition and in vitro antioxidant activity of Achyranthes aspera Linn. (Amaranthaceae) leaf extract. Int J Agric Technol 2012;8:143-56.

63. Zhongbing L, Guangjun B, Peter S, Belton C, Huiru D. Structureactivity relationship analysis of antioxidant ability and neuroprotective effect of gallic acid derivatives. Neurochem Int 2006;48:263-74.

64. Chia YC, Rajbanshi R, Calhoun C, Chiu RH. Anti-neoplastic effects of gallic acid, a major component of Toona sinensis leaf extract, on oral squamous carcinoma cells. Molecules 2010;15:8377-89

65. Raina K, Rajamanickam S, Deep G, Singh M, Agarwal R, Agarwa C. Chemopreventive effects of oral gallic acid feeding on tumor growth and progression in TRAMP mice. Mol Cancer Ther 2008;7:1258-67.

66. Sohi KK, Mittal N, Hundal MK, Khanduja KL. Gallic acid, an antioxidant, exhibits antiapoptotic potential in normal human lymphocytes: a Bcl-2 independent mechanism. J Nutr Sci Vitaminol 2003;49:221-7.

67. Patel SS, Goyal RK. Cardioprotective effects of gallic acid in diabetes-induced myocardial dysfunction in rats. Pharmacogn Res 2011;3:239-45.

\section{How to cite this article}

- Manjit Inder Singh Saggoo, Lovleen. Screening of total phenol and flavonoid content in different cytotypes of two species of Achyranthes linn. from western himalaya, India. Int J Pharm Pharm Sci 2017;9(10):205-210. 